\title{
PODSTAWOWE ZASADY STANDARYZACJI NAZW OBIEKTÓW FIZJOGRAFICZNYCH W POLSCE CZ. II
}

Słowa tematyczne: nazwy obiektów fizjograficznych, program standaryzacji, korekty językowe, rola władz lokalnych

Wspomniana na początku części pierwszej artykułu (Wolnicz-Pawłowska, 2019) standaryzacja nazw obiektów fizjograficznych w Polsce, przeprowadzana obecnie przez Komisję Nazw Miejscowości i Obiektów Fizjograficznych (dalej: $\mathrm{KNMiOF),} \mathrm{nie} \mathrm{jest} \mathrm{pierwszą} \mathrm{próbą} \mathrm{w} \mathrm{tym} \mathrm{zakresie.} \mathrm{Urzędowe} \mathrm{nazwy} \mathrm{około}$ 3000 takich obiektów z zachodnich i północnych terenów Polski, przyłączonych po II wojnie światowej, opublikowano w Monitorze Polskim po opracowaniu przez Komisję Ustalania Nazw Miejscowych w latach 1946-1951, a następnie wydano w formie książkowej (Rospond, 1951). Zadaniem Komisji było ustalenie polskich nazw z obszarów należących przez długi czas do innych organizmów państwowych i pozostających pod silnym wpływem języka niemieckiego'. Stosunkowo szybkie tempo prac sprzyjało utrzymaniu jednolitych zasad ustalania polskiego nazewnictwa. Niezależnie od tego, że dzisiaj nie wszystkie wytyczne uznalibyśmy za właściwe, a spora część zaproponowanych podówczas toponimów nie weszła na trwałe do społecznego obiegu, z punktu widzenia samego procesu standaryzacji przyjęte zasady stosowano dość konsekwentnie, kierując się przede wszystkim nadrzędnym celem: opracowaniem polskiego wykazu nazw geograficznych z obszaru tzw. Ziem Odzyskanych (por. Rączka, 1960).

${ }^{1}$ Głównym zadaniem Komisji było ustalenie polskich nazw miejscowości — nazw takich było ok. 32 000. Wśród nazw obiektów fizjograficznych znalazły się największe, najważniejsze gospodarczo i turystycznie obiekty, np. góry, pasma górskie, rzeki i jeziora. Działalność Komisji Ustalania Nazw Miejscowości z okresu 1946-1951 doczekała się wielu opracowań, z nowszych por. np. Wagińska-Marzec, 2000; Grabowski, 2000; Tomkiewicz, 2006. 
Opracowanie to sporządzili eksperci wielu specjalności (językoznawcy, historycy, geografowie i kartografowie), przy czym procedowali oni w trybie podobnym do tego, który przyjęto w pierwszym polskim organie nazewniczym w latach 30 . XX w. (zob. cz. I artykułu) ${ }^{2}$. Jeśli chodzi o nazwy terenowe, to poważnym problemem było zgromadzenie wiarygodnego materiału wyjściowego. Podstawowe formy nazw niemieckich czerpano z map. S. Rospond wyjaśniał: „Przy nazwach fizjograficznych wahania w brzmieniu niemieckim poszukiwanej nazwy mogą być większe i częstsze - jeżeli chodzi o szczegóły ortograficzne — gdyż odnośne komisje zmuszone były korzystać z różnych map niemieckich, nie zawsze dostatecznie czytelnych, nie dysponując gotowymi i pełnymi spisami nazw rzek, gór czy jezior" (Rospond, 1951, s. 792). Jakość i wiarygodność ocenianego materiału nazewniczego stanowi do dziś nierozwiązany problem w komisjach standaryzacyjnych, natomiast za sprawą Państwowego Rejestru Nazw Geograficznych (dalej: PRNG) znacznie poprawiła się dostępność spisów toponimów, zlokalizowanych dokładnie w terenie.

Zakrojone na szeroką skalę zbieranie i ustalanie nazw różnych obiektów fizjograficznych przeprowadzono przez Komisję w latach 1954-1975, między innymi przy pomocy językoznawców z wyższych uczelni ${ }^{3}$. Materiał ten, publikowany przez Urząd Rady Ministrów w zeszytach według układu powiatowego jako „Urzędowe nazwy miejscowości i obiektów fizjograficznych” (dalej: UN), nie został wydany w całości. Ukazały się zeszyty z ówczesnych województw: krakowskiego, kieleckiego, rzeszowskiego, lubelskiego, bydgoskiego, w niepełnym wymiarze z województw: łódzkiego, poznańskiego, warszawskiego, białostockiego, z województwa olsztyńskiego wydano tylko 2 zeszyty, a z województwa gdańskiego 1 zeszyt. Poszczególne nazwy są zlokalizowane poprzez przypisanie ich do danej wsi, jest to więc umiejscowienie bardzo niedokładne. Należy też podkreślić, że wbrew tytułowi tylko zeszyty z województw krakowskiego i rzeszowskiego zawierają nazwy urzędowe, w pozostałych są jedynie zestandaryzowane. Podczas zbierania materiałów dbano o autentyczność i zgodność z formą „ludową”, jednak przed zatwierdzeniem form zestandaryzowanych Komisja dostosowywała pisownię do polskiego języka ogólnego (por. np. Rączka, 1960, Lubaś, 1964). Wykazy UN wraz ze „Słownikiem nazw miejscowych Polski zachodniej i północnej" (Rospond, 1951) stanowią największy dotychczas zbiór nazw obiektów fizjograficznych poddanych ocenie państwowych komisji nazewniczych; dotyczą przeważającego obszaru kraju.

${ }^{2}$ Kontynuowaniu tradycji sprzyjał fakt, że członkiem powołanej w styczniu 1946 r. Komisji Ustalania Nazw Miejscowości i Obiektów Fizjograficznych (pod przewodnictwem S. Srokowskiego) był prof. K. Nitsch, który uczestniczył również jako członek w pracach przedwojennej komisji nazewniczej. Poza tym przyjęto za podstawę działania Komisji Zarządzenie Prezydenta z 1934 r. (Tomkiewicz, 2006, s. 173).

${ }^{3}$ Por. cenne opracowanie na ten temat Z. Babika (2019) w „Onomastikach”. 
Około 5200 nazw najważniejszych obiektów wodnych, górskich, nazw większych kompleksów leśnych i parków narodowych, a także nazw krain i regionów uwzględniono w tzw. gazeterze, czyli „Nazwach geograficznych Rzeczypospolitej Polskiej" (NGRP, 1991). Była to publikacja inspirowana zaleceniami Organizacji Narodów Zjednoczonych, aby poszczególne kraje wydawały oficjalne wykazy nazw geograficznych wraz z ich dokładną lokalizacją (współrzędnymi). „Gazetery” krajowe przeznaczone są do użytku międzynarodowego. Niektóre z uwzględnionych w NGRP nazw mają status urzędowych, inne - zestandaryzowanych. Zasady wyboru nazw obiektów geograficznych opracował zespół redaktorów z Państwowego Przedsiębiorstwa Wydawnictw Kartograficznych im. E. Romera, zaś ustaleniem poprawności form nazewniczych zajęła się Komisja Ustalania Nazw Miejscowości i Obiektów Fizjograficznych. Wstęp do tej publikacji zawiera m.in. „Zasady ustalania nazw geograficznych w Polsce”, zbieżne z wytycznymi zaprezentowanymi przez K. Rymuta w artykule z 1989 r., można więc sądzić, że wyszły spod jego pióra. Pisząc o zasadach ustalania nazw mikrotoponimów, podkreślono, że podstawą musi być z konieczności ich aktualna wymowa, ponieważ na ogół brak dokumentacji historycznej. Dołączono jednak do tej uwagi swoistą instrukcję: „Nazwom zapisanym w formie gwarowej nadajemy postać fonetyczną zgodną z zasadami języka ogólnopolskiego, pozbawiając je specyficznych, regionalnych cech. Np. w miejsce gwarowej wymowy $c, s, z$, odpowiadającej ogólnopolskiemu $c z, s z, \dot{z}$, wprowadzamy $c z, s z, \dot{z}$ (np. gwarowe Syja — ogólnopolskie Szyja), w miejsce gwarowej wymowy mnia-, odpowiadającej ogólnopolskiemu mia- wprowadzamy mia- (gw. Mniasto — ogólnopolskie Miasto). Gwarowe formy zleksykalizowane pozostawiamy bez zmian, np. pomorski Starogard (ogólnopolskie byłoby Starogród)" (NGRP, 1991, s. 8). Odnosząc się do pogranicza wschodniego z ludnością ,w zasadzie dwujęzyczną" (polsko-litewską, polsko-białoruską i polsko-ukraińską), wyjaśniono: „W tej sytuacji językowej urzędowe formy nazw geograficznych ustalane są w polskiej postaci językowej i ortograficznej, ale zachowane są specyficzne cechy białoruskie lub ukraińskie utrwalone w wymowie ludowej" (tamże, s. 7). Niestety, nie wskazano, o jakie specyficzne cechy chodzi oraz czy o wszystkie, czy tylko wybrane.

Na początku XXI w. osiągnięcia w dziedzinie hydrologii z jednej strony (atlasy, opracowania terminologiczne) oraz hydronimii z drugiej (seria monografii) pozwoliły na zgromadzenie reprezentatywnego zbioru współczesnych nazw wodnych z obszaru całej Polski. Prace standaryzacyjne przeprowadzono w latach 2003-2005. Przebiegały one we współpracy Komisji Nazw Miejscowości i Obiektów Fizjograficznych z Głównym Urzędem Geodezji i Kartografii, z udziałem zarówno hydrologów, jak i onomastów. Zasadniczym źródłem opiniowanych wykazów nazw były współczesne mapy topograficzne (głównie w skali 1:10 000) oraz przygotowywany wówczas „Atlas podziału hydrograficznego Polski” 
(Czarnecka, 2005) ${ }^{4}$. Efektem programu były dwa tomy serii „Nazewnictwo geograficzne Polski”, poświęcone hydronimom (Wolnicz-Pawłowska i in., 2006): w części pierwszej umieszczono nazwy wód płynących, źródeł i wodospadów, w części drugiej — nazwy wód stojących. Ogółem publikacja zawiera prawie 16000 hydronimów. Również w tej publikacji w „Przedmowie” umieszczono uwagi dotyczące zasad standaryzacji nazw (Cieślikowa i Wolnicz-Pawłowska, 2006). Komisja pod przewodnictwem K. Rymuta, a następnie A. Cieślikowej przyjęła pewne rozwiązania systemowe dla całego zbioru standaryzowanych hydronimów. Do nazw wodnych w formie wyrażeń przyimkowych (np. Koło Młyna 'staw'), w formie przymiotników (np. Krzywe 'jezioro') oraz w formie dopełniacza (np. Sabiny 'stawy') obligatoryjnie dodawano człon rodzajowy, umożliwiający odmianę przez przypadki i wybór właściwego wzorca odmiany (np. Staw koło Młyna, Jezioro Krzywe, Stawy Sabiny). Inną ważną decyzją było wprowadzenie jednolitego szyku w całym analizowanym zbiorze w nazwach złożonych typu Czarny Potok, Biały Rów, ale Jezioro Powidzkie, Kanat Grabowiecki. Po opracowaniu hydronimów KNMiOF w roku 2007 zajęła się nazwami jaskiń, jednak ten program standaryzacyjny uległ zawieszeniu wobec nowych zadań, stawianych przed Komisją.

Postęp w rozwiązaniach technicznych, przydatnych w porządkowaniu dużych baz danych oraz w informacji geograficznej, umożliwił utworzenie w $1989 \mathrm{r}$. Państwowego Rejestru Nazw Geograficznych i lepsze opracowanie materiału, m.in. dokładnej lokalizacji w terenie. Dzięki aktom prawnym uporządkowano także zasób terminów rodzajowych i relacje semantyczne między nimi ${ }^{5}$. Podstawą $\mathrm{w}$ bazie danych były nazwy wyekscerpowane $\mathrm{z}$ map topograficznych w skali 1:10 000 i 1:50 000. W latach 2012-2014 znacznie poszerzono ten zbiór o nazwy obiektów fizjograficznych z obszaru całej Polski w ramach programu zrealizowanego przez Główny Urząd Geodezji i Kartografii. Pozyskano wówczas od gmin 37269 nazw (Kacprzak i Zieliński, 2017, s. 88). W 2017 r. PRNG zawierał 123018 nazw obiektów fizjograficznych o różnym statusie (urzędowe, zestandaryzowane, niestandaryzowane $\mathrm{i}$ in.). Około 60000 tych nazw stanowią nazwy terenowe, takie jak nazwy łąk, pól, lasów i ich części, polan, uroczysk, bagien itp. (tamże, s. 90). Ze względu na to, że znaczna część tego zbioru nie przeszła procesu standaryzacji, od 2014 r. prowadzone są systematyczne prace w Komisji

\footnotetext{
${ }^{4}$ Należy zaznaczyć, że zarówno topografowie, jak i hydrolodzy zbierają nazwy w terenie w podobny sposób jak dialektolodzy; zebrany materiał przed publikacją poddawany jest ocenie poprawnościowej, por. Gołaski, 2002.

${ }^{5}$ Ustawa z dn. 17 maja 1989 r. Prawo geodezyjne i kartograficzne (Dz. U. z 1989 r. Nr 30, poz. 163 z późn. zm.). Szczegółowy sposób postępowania określa Rozporządzenie Ministra Administracji i Cyfryzacji z dn. 14 lutego 2012 r. w sprawie państwowego rejestru nazw geograficznych (Dz. U. z 2012 r. Nr 255, poz. 309 z późn. zm.).
} 
Nazw Miejscowości i Obiektów Fizjograficznych nad zaopiniowaniem materiałów, dostarczanych przez PRNG w postaci tabel według poszczególnych województw. Po przejrzeniu tabel z 12 województw Komisja wstępnie zaopiniowała ponad 53000 nazw (stan z początku 2020 r.). Tabele z uwagami Komisji przesyłane są do gmin z prośbą o wyjaśnienia i weryfikację. Po otrzymaniu odpowiedzi od gmin i naniesieniu poprawek możliwe będzie dalsze postępowanie standaryzacyjne zakończone uchwałą Komisji. Wykazy nazw zestandaryzowanych są podstawą opracowania i publikacji wykazów nazw urzędowych przez właściwego ministra. Niezależnie od prac nad nazwami niestandaryzowanymi Komisja w normalnym trybie zajmuje się wnioskami od gmin, które stwierdziły rozbieżności między istniejącym wykazem urzędowych nazw obiektów fizjograficznych oraz stanem faktycznym na miejscu; najczęściej są to wnioski o zniesienie nieużywanych obecnie nazw. Przeprowadzana akcja weryfikacyjna i standaryzacyjna daje nadzieję na opracowanie zaktualizowanych wykazów urzędowych polskich nazw obiektów fizjograficznych z obszaru całego kraju.

Prace standaryzacyjne postawiły z nową ostrością problem interpretacji i oceny zapisów źródłowych o gwarowej lub niepolskiej postaci oraz zgodność brzmienia i pisowni nazwy z zasadami ogólnego języka polskiego. Nazwy terenowe mają na ogół słabe poświadczenia historyczne, zaś źródła współczesne (mapy i informacje od administracji gminnej) często podają formy gwarowe, mniejszościowe lub w różny sposób zniekształcone. Wracają więc problemy, opisane już w latach 30. XX w. oraz w późniejszych publikacjach członków kolejnych komisji normatywnych. Na materiale nazw obiektów fizjograficznych z województwa lubelskiego przedstawiłam najczęstsze typy nazw pod względem ich zgodności z normą ogólnopolską (Wolnicz-Pawłowska, 2015). Pierwszy typ to nazwy zgodne z normą polszczyzny ogólnej. Takie nazwy przeważają w wykazach przygotowanych przez PRNG na posiedzenia KNMiOF i nie stwarzają na ogół problemów poprawnościowych, np. Błota, Dąbrowa, Kruszyna, Pasieka, Tatarski Las. Zdarza się jednak, że wyjaśnienia wymaga forma dopełniacza, np. przy nazwach takich jak Łosie, Korzenna, Bartków. Przykłady takich nazw obiektów fizjograficznych nie różnią się co do swej charakterystyki fleksyjnej od nazw miejscowości, opisanych w słownikach poprawnościowych (por. zwłaszcza Cieślikowa, 2002, Czopek-Kopciuch, Bijak i Cieślikowa, 2011). W tej grupie mieszczą się także nazwy, które mają utrwalone regionalne wzorce odmiany, np. Morgi, Mórg albo Morgi, Morgów; Smugi, Smug albo Smugi, Smugów. Drugą grupę tworzą nazwy z cechami gwarowymi: np. formy z mazurzeniem, ze ścieśnionymi samogłoskami, uproszczonymi grupami spółgłoskowymi, rozłożoną nosowością itp., np. Śmierdzacka, Głowcyn, Drozyna; Losek, Rzyczysko, Ćwirć; Paświsko, Tracht, Kampa (Wolnicz-Pawłowska, 2020). Czasem nie chodzi o zjawisko gwarowe, ale błędy ortograficzne wynikające m.in. z zapisu potocznej wymowy, jak 
w przykładach Czcińce (zamiast Trzcińce), Bożysko (zamiast Borzysko), Zagront (zamiast Zagrą), Hechło (zamiast Chechło), Płuska (zamiast Płóska), Hród (zamiast Hrud). Najczęściej zapisy takie pojawiają się w źródle określanym jako „wywiad terenowy”, tzn. w materiałach pozyskanych od gmin w latach 2012-2014. Niewielką, ale pracochłonną dla członków Komisji grupę nazw stanowią nazwy błędnie zapisane lub odczytane ze źródła, omyłkowe, zdefektowane. Mogą być one efektem pomyłki w zapisie w trakcie przygotowywania materiałów na posiedzenia KNMiOF, ale trafiają się także błędy w wykorzystanych źródłach, np. na mapach ${ }^{6}$. Oczywiste błędy są najczęściej poprawiane przez samą Komisję, np. Czerwentyny poprawiono na Czetwertyny, Zabrowarokie na Zabrowarskie. ${ }^{7}$ Pozostałe nazwy kierowane są do dodatkowych wyjaśnień w danej gminie ${ }^{8}$. Trzeba zaznaczyć, że w obiegu administracyjnym funkcjonuje wiele nazw, które językoznawca bez wahania kwalifikuje jako błędne lub niepoprawne, jednak zadaniem Komisji nie jest rekonstrukcja nazw zgodna z etymologią, gdyż zmiany są spowodowane nie zawsze jasnymi analogiami.

Na pograniczach spotykamy nazwy w języku mniejszości, np. ukr. Bir ${ }^{9}$ (por. ukr. bir, boru, pol. bór, boru), Łuczka (por. ukr. łuczka ‘łączka'), niem. Enteloch ('kacza jama'?). Często takie zapożyczenia mają postać różnych adaptacji fonetyczno-morfologicznych lub hybryd, np. ukraińsko-polskich (Hrudek, Krugłe Błoto).

Ten zbiór nazw, zróżnicowany pod względem poprawności i normy ogólnopolskiej, niełatwo uporządkować. Jak wspomniałam w części pierwszej artykułu, w procesie standaryzacji nazw obiektów fizjograficznych musimy uwzględniać założenia obecnej polskiej polityki językowej, która zmierza do ochrony i stabilizacji polskich nazw własnych w kraju i za granicą, przy równoczesnym respektowaniu nazw własnych w językach mniejszościowych, w zakresie wyznaczonym w ustawie o mniejszościach. Oznacza to, że w wykazie polskich

${ }^{6}$ Analiza nazewnictwa na mapach wskazuje, że kartografowie korzystają z istniejących już map i niekiedy powielają błędy poprzedników (por. Włoskowicz, 2015). Przykładem błędnego zapisu pochodzącego z mapy jest napis Wrzesklewie, zweryfikowany przez gminę jako Bezchlebie.

${ }^{7}$ Por. taką samą praktykę przed wojną: „Gdy błąd był rażący, można było go usunąc bez dalszych dochodzeń. Np. mając do wyboru formy Ostrówek i Ostrówiek [...], Karpin — Kaspin [...], nie można było mieć wątpliwości, że tylko pierwsza z podanych form jest prawidłowa”" (Buławski, 1930, s. 128).

${ }^{8}$ W wyniku weryfikacji gminy sprostowały np. zapisy, takie jak Biaka Droga, Debre, Radoniel, stwierdzając, że prawidłowe formy to Biała Droga, Debra, Radomiel. Ten tryb postępowania (konsultacje z lokalnymi samorządami) ma swój pierwowzór w działalności przedwojennej komisji nazewniczej (Buławski, 1930, s. 127).

${ }^{9}$ Zapis Bir, -ru w materiałach przygotowanych na posiedzenie Komisji wymaga dyskusji i decyzji, czy ostatecznie w urzędowych wykazach ma się znaleźć forma Bir, dop. Biru (jak zapewne wspomniany zapis odczyta przeciętny użytkownik), spolonizowana forma Bór, dop. Boru czy też zgodna z językiem mniejszości, ale niepoprawna na gruncie polszczyzny odmiana Bir, dop. Boru. 
urzędowych nazw geograficznych nie mogą występować nazwy zawierające głoski (połączenia głosek) i litery niewystępujące w rodzimych polskich wyrazach, np. $v, t h, l j, x, \ddot{o}, s i^{10}$. Nazwa urzędowa musi być zgodna pod względem zapisu z obowiązującymi polskimi regułami ortograficznymi, w szczególności regułami pisowni łącznej i rozdzielnej oraz pisowni wielką i małą literą.

Ponadto każda nazwa musi należeć do jakiegoś paradygmatu polskiego, tzn. musi się odmieniać według jakiegoś polskiego wzorca. Z tego względu np. nie można stosować wzorców odmiany białoruskiej czy ukraińskiej. Bez odmiany pozostają tylko nazwy w postaci wyrażenia przyimkowego, np. Na Skraju, Między Rolami. Jeśli występują dublety nazewnicze, to pierwszeństwo dajemy formie polskiej, a nie mniejszościowej, np. przy oboczności Haupthalej // Główna Droga Komisja pozytywnie zaopiniowała drugą formę. Podobnie postępujemy przy dubletach z nazwą gwarową i ogólnopolską, wybierając formę ogólnopolską.

W procedowaniu zwracamy baczną uwagę na spójność nazewniczą, tzn. jeśli nazwa terenowa pochodzi od jakiejś urzędowej nazwy miejscowości czy innego obiektu geograficznego, to harmonizujemy nazwę standaryzowaną z urzędową, np. Nortowy Rów zmieniamy na Nartowy Rów ze względu na nazwę wsi Narty.

Komisja w obecnym składzie zrezygnowała z systemowego porządkowania całego zbioru standaryzowanych nazw, m.in. z wprowadzenia jednolitego szyku w nazwach wieloczłonowych oraz uzupełniania terminów rodzajowych w nazwach przyimkowych i przymiotnikowych; jest to zmiana w stosunku do zasad przyjętych przy standaryzacji hydronimów (zob. wyżej). Jednocześnie — zgodnie z wieloletnią tradycją normalizacyjną — nazwy z mazurzeniem, z rozłożoną miękkością spółgłosek wargowych oraz z (dawnymi) pochylonymi samogłoskami traktowane są jako niepoprawne. Zgodnie z zasadą opisaną przez K. Rymuta przy zapisach gwarowych ,nie modyfikuje się struktury słowotwórczej i nie zmienia końcówek fleksyjnych" (Rymut, 1989), przy czym ostatnia uwaga odnosi się właściwie do rodzaju gramatycznego i wzorca odmiany danej nazwy, a nie do postaci fonetycznej końcówki. Zatem w przykładach śląskich typu Głambokoł (tj. 'Głęboka'), Lempkowoł-Górka (tj. 'Lempkowa Górka') końcówka przymiotnika rodzaju żeńskiego powinna w formie urzędowej przybrać fonetyczną postać ogólnopolską $-a^{11}$.

${ }^{10}$ Możliwe jest odstępstwo od tej zasady wówczas, gdy w nazwie zestawionej jeden z członów pochodzi np. od obcego nazwiska, por. Okopy Linii Berthold, Wyspa Rehdanza.

${ }^{11}$ Pozostawienie zapisu $\mathrm{z} \ell$ na końcu powoduje, że polski użytkownik automatycznie przypisuje takim formom rodzaj męski. W przykładzie Głambokoł decyzji standaryzacyjnej i ustalenia (prócz końcówki) wymaga także zapis samogłoski nosowej: czy pozostawić zapis zgodny z gwarową (i regionalną) wymową -am- (Gtamboka), czy dostosować do ogólnopolskiej normy ortograficznej (Głęboka). W tej kwestii członkowie Komisji nie są jednomyślni i nie podjęto jeszcze uchwały. 
Szczególną uwagę Komisja poświęca nazwom mniejszościowym i zapożyczonym, które w materiałach do zaopiniowania występują jako jedyne spotykane formy. W tym zakresie główny kierunek prac Komisji zmierza do adaptacji tego typu przykładów do polskiej fonetyki, ortografii i fleksji, co jest kontynuacją dotychczasowych zasad, stosowanych przez polskie komisje standaryzacyjne (por. Rymut, 1989, 1999). Pod uwagę brana jest wielowiekowa tradycja adaptacyjna, np. w wielu nazwach miejscowości na pograniczu polsko-ukraińskim występuje ukr. $h$ w miejscu $g$ (np. Hrubieszów), $u$ w miejscu dawnej samogłoski nosowej (np. Dubów) oraz pełnogłos (np. Horodto, Bereza) (por. Rieger, 1992). Zgodnie z tą tradycją również w nazwach obiektów fizjograficznych pozostawiamy te cechy jako specyficzne dla regionu. Bardziej skomplikowana jest sytuacja na pograniczu zachodnim, gdzie dawne adaptacje z języka niemieckiego w nazwach geograficznych programowo polonizowano po II wojnie światowej (por. Srokowski, 1950).

Porządkowanie zbioru nazw terenowych — podobnie zresztą jak i nazw miejscowości i ich części — komplikuje się wobec strukturalnych sprzeczności występujących między pryncypiami, którymi kieruje się Komisja i tymi, którymi kierują się lokalne społeczności, w szczególności samorządy. W procesie standaryzacji nazw geograficznych ustawodawca przewidział pewne prerogatywy i role dla samorządu gminnego. Wymienię trzy:

1. Według ustawy z 2003 r. Komisja Nazw Miejscowości i Obiektów Fizjograficznych ustala urzędowe nazwy oraz zmienia i znosi istniejące urzędowe nazwy miejscowości i obiektów fizjograficznych na wniosek gminy.

2. Niezależnie od KNMiOF rada gminy na mocy ustawy z dn. 8 marca $1990 \mathrm{r}$. o samorządzie terytorialnym uchwala nazwy ulic i placów będących drogami publicznymi oraz nazwy dróg wewnętrznych.

3. W programie kompletowania państwowego rejestru nazw geograficznych nazwy niestandaryzowanych obiektów fizjograficznych standaryzuje Komisja, natomiast gminy dostarczają materiały i opiniują wykaz.

Obszar współdziałania KNMiOF i samorządów zasadniczo określa ustawa z 2003 r. o urzędowych nazwach miejscowości i obiektów fizjograficznych. Współcześnie Komisja nie tworzy sama nazw urzędowych, ale przede wszystkim opiniuje wnioski, nadsyłane przez gminy. Po uchwaleniu w 2005 r. ustawy o mniejszościach narodowych Komisja rozpatruje również wnioski gmin o nadanie dodatkowych nazw w językach mniejszościowych.

W polityce nazewniczej państwa (reprezentowanego przez Komisję) i samorządów są pewne punkty kolizyjne. Punkt widzenia Komisji ma charakter całościowy

W przykładzie Lempkowoł-Górka - ze względu na pochodzenie pierwszego członu od nazwisk typu Lempke, Lempka itp. — takiego dylematu nie ma. 
i systemowy. W świadomości członków Komisji istnieją dwa zbiory nazw: zbiór nazw geograficznych w obrębie kraju oraz za granicą. Członkowie Komisji mają dużą wiedzę o obu tych zbiorach i wykorzystują swoje kompetencje w tym zakresie w trakcie rozstrzygania kwestii spornych. Ujęcie systemowe przejawia się w traktowaniu ogółu nazw własnych (zarówno geograficznych, jak i osobowych) we wzajemnym powiązaniu. Sprzyjało to wprowadzaniu jednolitych reguł nazewniczych dla obszaru całego kraju, co było widoczne zwłaszcza w postępowaniu Komisji pod koniec XX w. i na początku XXI w. Jako przykład podam cytowane wyżej stanowisko Komisji z lat 80. XX w.: „Człony dyferencyjne typu NowyStary stawiamy zawsze przed członem utożsamiającym” (Rymut, 1989).

W kwestii poprawności językowej Komisja kieruje się normą ogólnopolską (wspólnota komunikatywna VI stopnia wg L. Zabrockiego), m.in. ściśle przestrzega zasad pisowni nazw z łącznikiem, np. Dąbrówka-Kolonia.

W procesie standaryzacji polska Komisja dużą wagę przykłada do tradycji, przy czym uwzględniona jest pełna znana nam historia całej wspólnoty narodowej. Komisja stara się harmonizować swoje decyzje z ogólnymi celami i zasadami polityki językowej państwa (np. preferując formy polskie w nazwach urzędowych, a nie mniejszościowe).

Punkt widzenia samorządu gminy różni się od punktu widzenia KNMiOF, między innymi przez ujęcie fragmentaryczne, ograniczone przestrzennie i czasowo. We wnioskach gmin widać brak ujęcia systemowego na poziomie krajowym, nie ma świadomości istnienia ogólnopolskiego systemu nazewniczego i powiązania między nazwami, czy to formalnego, czy etymologicznego. Jeśli w ogóle samorząd gminny ma świadomość istnienia zbioru nazw obiektów geograficznych, to na poziomie lokalnej wspólnoty (wspólnota komunikatywna III stopnia wg L. Zabrockiego), rzadko odnosząc się nawet do nazewnictwa w sąsiedniej gminie czy powiecie. Jest natomiast niewątpliwie świadomość powiązania nazewnictwa w dokumentacji gminnej i tu samorząd dąży np. do ujednolicenia nazwy wsi, nazwy siedziby sołectwa i nazwy obrębu geodezyjnego. Władze gminne najchętniej operowałyby tylko takim zestawem urzędowych nazw, który jest potrzebny w dokumentach finansowych i ewidencyjnych, ewentualnie w promocyjnych materiałach gminy. Z tego względu często wnioski do Komisji dotyczą zniesienia nazw urzędowych części wsi, które z punktu widzenia gminy nie pełnią istotnych funkcji administracyjnych.

Jeśli chodzi o rolę tradycji, to najczęściej działa ona w odniesieniu do dokumentacji gminnej z ostatnich 20-30 lat, chociaż zdarzają się wyjątki, zwłaszcza w gminach o walorach turystycznych.

Poprawność językowa oceniana jest według normy lokalnej (niejednokrotnie gwarowej), a często także według stanu rzeczy w istniejącej dokumentacji gminnej. 
Najczęstszym przykładem jest nieprzestrzeganie pisowni z łącznikiem w nazwach typu Dąbrówka-Kolonia. Komisja w tej kwestii nie uznaje jednak wyjątków.

Harmonizacja z polityką państwa występuje rzadko i raczej nie ma świadomości potrzeby takich działań.

$\mathrm{Na}$ podstawie przesyłanych do Komisji wniosków można sądzić, że punkt widzenia samorządu określają interesy biurokracji samorządowej i mieszkańców, przede wszystkim niechęć do nakładów finansowych w przypadku zmian w nazewnictwie (częsta motywacja mieszkańców) oraz dążenie do zachowania status quo w istniejącej dokumentacji.

\section{LITERATURA}

Czarnecka, H. (red.). (2005). Atlas podzialu hydrograficznego Polski [Atlas of the hydrographic division of Poland] (cz. 1. Mapy w skali 1:200 000. Cz. 2. Zestawienie zlewni). Warszawa: IMGW.

Babik, Z. (2019). Tzw. akcja UN-owska (1954?-1970?) — projekt, przebieg, efekty, próba oceny [The campaign to gather terrain names in Poland (1954?-1970?) - The project, realization, effects, and its attempt at evaluation]. Onomastica, 63, 291-313.

Buławski, R. (1930). Metoda opracowania wykazu osiedli zawartego w „Skorowidzu miejscowości Rzeczypospolitej Polskiej” [Method of developing a list of settlements contained in the „Index of the localities of the Republic of Poland"]. Wiadomości Stużby Geograficznej, 2, 124-140.

Cieślikowa, A. (red.). (2002). Mały stownik odmiany nazw wlasnych [A small dictionary of a variation of proper names]. Kraków: Instytut Języka Polskiego PAN, TMJP.

Cieślikowa, A. i Wolnicz-Pawłowska, E. (2006). Przedmowa [Preface]. W: E. Wolnicz-Pawłowska i in., Nazewnictwo geograficzne Polski. T. I. Hydronimy. Cz. 1. Wody płynace, źródła, wodospady [Geographical names of Poland. Vol. I. Hydronyms. Part 1. Flowing waters, sources, waterfalls] (s. VII-XIV). Warszawa: GUGiK.

Czopek-Kopciuch, B., Bijak, U. i Cieślikowa, A. (2011). Mały stownik nazw polskich miast, państw Europy, ich stolic i mieszkańców [A small dictionary of the names of Polish cities, European countries, their capitals and inhabitants]. Warszawa: Rytm.

Gołaski, J. (2002). Zbieranie i opracowywanie nazw geograficznych. Przewodnik toponimiczny. $C z$. I. Zbieranie nazw $w$ terenie [Collecting and elaborating geographical names. Toponymic Guide. Part 1. Collecting Names in the Field]. Warszawa: GUGiK.

Grabowski, P. (2000). Działalność Komisji Ustalania Nazw Miejscowych na terenach Ziem Odzyskanych w latach 1946-1951 [Activities of the Commission for Establishing Names of Localities in the Recovered Territories in 1946-1951]. W: W. Wernerowa, J. Ostrowski (red.), Kartografia polska XIX wieku w dorobku Bolestawa Olszewicza [Polish cartography of the 19th century in the works of Bolesław Olszewicz] (s. 47-59). Warszawa: Instytut Historii Nauki PAN.

Kacprzak, J. i Zieliński, J. (2017). Problematyka standaryzacji i wizualizacji danych Państwowego Rejestru Nazw Geograficznych (PRNG) [Standardization and visualization of data in the National Register of Geographical Names (NRGN)]. Polish Cartographical Review. Suplement w języku polskim, 2(1), 85-92.

Lubaś, W. (1964). Nazwy terenowe pow. jasielskiego i krośnieńskiego [Terrain names of the Jasło and Krosno counties]. Cz. II. Onomastica, 9, 123-163.

NGRP - Nazwy geograficzne Rzeczypospolitej Polskiej [Geographical Names of the Republic of Poland]. (1991). Warszawa-Wrocław: PPWK. 
Rąc zka, E. (1960). W piętnastolecie działalności Komisji Ustalania Nazw Miejscowości i Obiektów Fizjograficznych w Polsce Ludowej [On the fifteenth anniversary of the Commission for Establishing Names of Localities and Physiographic Objects in People's Poland]. Onomastica, 6, 323-327.

Rieger, J. (1992). Elementy ukraińskie w toponimii polskiej i w toponimii Polski [Ukrainian elements in Polish toponymy and in toponymy of Poland]. Acta Universitatis Lodzensis. Folia Linguistica, 27, 247-253.

Rospond, S. (1951). Stownik nazw geograficznych Polski zachodniej i pótnocnej [Dictionary of geographical names of Western and Northern Poland] (cz. 1-2). Wrocław-Warszawa: PTG.

Rozporządzenie Ministra Administracji i Cyfryzacji z dnia 14 lutego 2012 r. w sprawie państwowego rejestru nazw geograficznych (Dz. U. z 2012 r. Nr 255, poz. 309 z późn. zm.).

Rymut, K. (1989). W sprawie zasad ustalania nazw geograficznych [On the rules for determining geographical names]. W: M. Majtán (red.), Aktuálne úlohy onomastiky z hl'adiska jazykovej politiky a jazykovej kultury [Current Tasks of Onomastics from the Point of View of Language Policy and Language Culture] (s. 36-42). Bratislava: Jazykovedný ústav Ludovita Štúra Slovenskej akadémie vied.

Rymut, K. (1999). Problemy z kodyfikacją nazw genetycznie białoruskich na Białostocczyźnie [Problems with the codification of genetically Belarusian names in the Bialystok region], W: Z. Abramowicz, L. Dacewicz (red.), Nazewnictwo na pograniczach etniczno-językowych [Names and naming on ethnic-linguistic borderlands] (s. 257-261). Białystok: Libra.

Srokowski, S. (1950). Akcja przywracania polskich nazw miejscowości na Ziemiach Odzyskanych [The action of restoring Polish place names in the Regained Territories]. Przeglad Geograficzny, 22, 305-309.

Tomkiewicz, R. (2006). O działalności Komisji Ustalania Nazw Miejscowych i Obiektów Fizjograficznych na terenie Warmii i Mazur. W: J. Duma (red.), Onomastyka regionalna (s. 170180). Olsztyn: Ośrodek Badań Naukowych im. W. Kętrzyńskiego.

Urzędowe nazwy miejscowości i obiektów fizjograficznych [Official Names of Localities and Physiographical Objects] (1962-1975) (z. 1-197). Warszawa: Urząd Rady Ministrów.

Ustawa z dnia 17 maja 1989 r. Prawo geodezyjne i kartograficzne (Dz. U. z 1989 r. Nr 30, poz. 163 z późn. zm.).

Ustawa z dnia 7 października 1999 r. o języku polskim (Dz. U. z 1999 r. Nr 57, poz. 324 $\mathrm{z}$ późn. $\mathrm{zm}$.).

Ustawa z dnia 29 sierpnia 2003 r. o urzędowych nazwach miejscowości i obiektów fizjograficznych (Dz. U. z 2003 r. Nr 166, poz. 1612).

Ustawa z dnia 6 stycznia 2005 r. o mniejszościach narodowych i etnicznych oraz o języku regionalnym (Dz. U. z 2005 r. Nr 17, poz. 141).

Wagińska-Marzec, M. (2000). Jak zmieniano nazwy miejscowości na Warmii i Mazurach po 1945 roku [How were the names of places in Warmia and Mazury changed after 1945.]. W: Z. Mazur (red.), Wspólne dziedzictwo? Ze studiów nad stosunkiem do spuścizny kulturowej na Ziemiach Zachodnich $i$ Pótnocnych [Common heritage? Studies on the attitude to the cultural heritage in the Western and Northern Territories] (s. 59-107). Poznań: Instytut Zachodni.

Włoskowicz, W. (2015). Toponomastyczna praca topografa w Austro-Węgrzech i w II Rzeczypospolitej [A Topographer's Toponymic Work in Austria-Hungary and in the Second Republic of Poland]. Prace Językoznawcze, 17(3), 137-153.

Wolnicz-Pawłowska, E. (2005). Standaryzacja narodowa mikrotoponimów na pograniczach językowych. Stan obecny, perspektywy, postulaty [National standardization of microtoponyms on language borderlands. The present state, prospects, postulates]. W: M. Łesiów, M. Olejnik (red.), Mikrotoponimia na pograniczach językowo-kulturowych [Microtoponymy on the linguistic and cultural borderlands] (s. 165-179). Lublin: UMCS. 
Wolnicz-Pawłowska, E. (2015). Z problemów standaryzacji nazw obiektów fizjograficznych Lubelszczyzny. Nowa sytuacja prawna, nowe i stare problemy [On the problems of standardization of names of physiographic objects of the Lublin region. New legal situation, new and old problems]. W: F. Czyżewski, M. Olejnik, A. Pihan-Kijasowa (red.), Pogranicza słowiańskie w opisach językoznawczych. W 110 rocznice urodzin Profesora Władysława Kuraszkiewicza (1905-1997) [Slavic borderlands in linguistic descriptions. On the 110th anniversary of the birth of Professor Władysław Kuraszkiewicz (1905-1997)] (s. 261-270). Lublin: Polihymnia.

Wolnicz-Pawłowska, E. (2019). Podstawowe zasady standaryzacji nazw obiektów fizjograficznych w Polsce. Cz. I [The Basic Principles of the Standardization of the Names of Physiographic Objects in Poland. Part I]. Onomastica, 63, 119-129.

Wolnicz-Pawłowska, E. (2020), Ślady polskiej wymowy gwarowej w nazwach terenowych w Państwowym Rejestrze Nazw Geograficznych [Traces of the Polish dialectal pronunciation of names of uninhabited geographical features included in the National Register of Geographical Names] (złożone do druku).

Wolnicz-Pawłowska, E., Duma, J., Rieger, J., Czarnecka, H., Głowacka, B., Hołdakowska, J. i Sawicka, E. (2006). Nazewnictwo geograficzne Polski. T. I: Hydronimy. Cz. 1. Wody płynace, źródła, wodospady. Cz. 2: Wody stojące [Geographical Names of Poland. Vol. I. Hydronyms. Part 1. Flowing waters, sources, waterfalls. Part 2. Standing waters]. Warszawa: GUGiK.

Zabrocki, L. (1968). Zasięgi wewnętrznego językowego magazynowania nazw jednostkowych [Ranges of Internal Linguistic Storage of Singular Names]. W: S. Hrabec i in. (red.), Symbolae philologicae in honorem Vitoldi Taszycki (s. 416-424), Wrocław-Warszawa-Kraków: Zakład Narodowy im. Ossolińskich.

\section{SUMMARY}

\section{THE BASIC PRINCIPLES OF THE STANDARDIZATION OF THE NAMES OF PHYSIOGRAPHIC OBJECTS IN POLAND. PART II}

In the second part of the article, the history of standardization programmes concerning the names of physiographic objects is discussed. The basis of the standardization programme currently followed by the Commission on Names of Localities and Physiographic Objects is described. The paper also presents the criteria of linguistic correctness adopted by the previous standardization commissions as well as by the present one. Issues of linguistic correctness of geographical names with dialectal properties and of names borrowed from minority languages are discussed. Attention is paid to some structural discrepancies in the approaches to the issue of correctness taken by the Commission on Names of Localities and Physiographic Objects and by local authorities.

Keywords: names of physiographic objects, standardization programmes, linguistic correctness, role of local authorities 